\title{
Studies on the Reserve of Anterior Pituitary Hormones, HGH, ACTH and LH, in Patients with Primary Thyroid Disorders
}

\author{
Takashi NUNOKAWA \\ Second Department of Internal Medicine, Tohoku University School of Medicine, \\ Sendai, Japan (Director : Professor T. Torikai)
}

In order to study the pituitary reserve of various pituitary hormones in patients with throid disorders, plasma growth hormone (HGH), adrenocorticotropic hormone $(\mathrm{ACTH})$, luteinizing hormone (LH) and plasma 11-hydroxycorticosteroids (11-OHCS) in response to insulin-induced hypoglycemia and $\mathrm{HGH}$ to arginine infusion were examined. Twenty patients with hyperthyroidism (including 6 patients with periodic paralysis) and 8 patients with primary hypothyroidism were subjected to the studies. In some of the cases, studies were repeated after treatments when their condition became euthyroid. Insulin tolerance test was performed by injecting $0.1 \mathrm{u} / \mathrm{kg}$ of regular insulin and arginine infusion test by infusing $0.5 \mathrm{~g} / \mathrm{kg}$ of 1 -arginine for $30 \mathrm{~min}$. Plasma pituitary hormones were measured by coated charcoal radioimmunoassay and plasma 11-OHCS by fluorometric technique with De Moor's method.

1. Responses of plasma HGH to both insulin-induced hypoglycemia and arginine infusion were deficient in both hyperthyroid and hypothyroid groups, especially in the hypothyroid group. The average peak value of plasma HGH to insulin-induced hypoglycemia was $14.0 \mathrm{~m} \mu \mathrm{g} / \mathrm{ml}$ after insulin injection in the hyperthyroid group and $2.8 \mathrm{~m} \mu \mathrm{g} / \mathrm{ml}$ in the hypothyroid group compared with $27.3 \mathrm{~m} \mu \mathrm{g} / \mathrm{ml}$ in normal subjects. Blood sugar levels fell comparably to normal subjects in both groups. The average peak value of plasma $\mathrm{HGH}$ to arginine infusion was $6.0 \mathrm{~m} \mu \mathrm{g} / \mathrm{ml}$ in the hyperthyroid group and 1.3 $\mathrm{m} \mu \mathrm{g} / \mathrm{ml}$ in the hypothyroid group compared with $30.2 \mathrm{~m} \mu \mathrm{g} / \mathrm{ml}$ in normal subjects.

2. In order to assess the role of adrenergic mechanism in HGH secretion in hyperthyroidism, 6 patients with hyperthyroidism were also subjected to insulin tolerance test after administration of propranolol, a beta blocker, either $30 \mathrm{mg} /$ day orally for 2 weeks or by a single intravenous injection of $6 \mathrm{mg}$. But the responses of plasma HGH were not significantly different from those values which were obtained before administration.

3. The responses of plasma ACTH to insulin-induced hypoglycemia were diminished in both groups. The average peak value of ACTH to insulin was $142 \mu \mu \mathrm{g} / \mathrm{ml}$ in the hyperthyroid group and $91 \mu \mu \mathrm{g} / \mathrm{ml}$ in the hypothyroid group compared with $181 \mu \mu \mathrm{g} / \mathrm{ml}$ in normal subjects.

4. The responses of plasma LH to insulin were also impoverished in both groups. The average peak value of plasma LH after insulin was $39 \mu \mathrm{g} / \mathrm{dl}$ in the hyperthyroid group and $26 \mu \mathrm{g} / \mathrm{dl}$ in the hypothyroid group compared with $61 \mu \mathrm{g} / \mathrm{dl}$ in normal subjects.

5. The increments of plasma 11-OHCS in response to insulin-induced hypoglycemia 
were $9 \mu \mathrm{g} / \mathrm{dl}$ in the hyperthyroid group and $10 \mu \mathrm{g} / \mathrm{dl}$ in the hypothyroid group compared with $15 \mu \mathrm{g} / \mathrm{dl}$ in normal subjects.

6. The disappearance rate of ${ }^{131} \mathrm{I}-\mathrm{HGH}$ from the plasma was measured in 2 patients with hyperthyroidism and a patient with hypothyroidism. Following a single intravenous injection of ${ }^{131} \mathrm{I}-\mathrm{HGH}$ using $0.1 \mu \mathrm{g}(200 \mathrm{mc} / \mathrm{mg})$, the disappearance curve in plasma plotted semilogarithmically against time indicated that the system was composed at least of 2 exponentials, the average half-life for the 2 nd component was $68 \mathrm{~min}$. in 2 patients with hyperthyroidism and $101 \mathrm{~min}$. in a case of hypothyroidism against $59 \mathrm{~min}$. in 2 normal subjects.

7. After treatment, the responses of plasma HGH, ACTH, LH and 11-OHCS almost returned to normal, though the recovery was better and sooner in patients with hyperthyroidism. For example, the average peak value of plasma HGH to insulin-induced hypoglycemia rose up to $34.2 \mathrm{~m} \mu \mathrm{g} / \mathrm{ml}$ in 6 patients treated for hyperthyroidism and 13.3 $\mathrm{m} \mu \mathrm{g} / \mathrm{ml}$ in 3 patients treated for hypothyroidism.

8. From the above results, it was concluded that the pituitary reserve of $\mathrm{HGH}$, ACTH and LH was decreased in patients with thyroid disorders. As causative factors for diminished secretion of $\mathrm{HGH}$ which showed the most marked diminution among pituitary hormones examined, the altered regulations of HGH secretion at the level of pituitary and/or higher central nervous system were suggested in both hyperthyroid and hypothyroid states through oversecretion or deficient secretion of thyroid hormones, respectively. A possible role of adrenergic mechanism for diminished secretion of $\mathrm{HGH}$ was not demonstrated from the effect of adrenergic blockade in patients with hyperthyroidism. Changes in metabolic rates of $\mathrm{HGH}$ were not excluded. The same sort of possibilities might be responsible for diminished secretions of ACTH and LH.

(See pp. 115 128) 


\section{甲状腺機能異常症における下垂体前葉ホルモン，特に HGH, ACTH および LH の分泌能について}

東北大学医学部第二内科教室（指導 鳥飼龍生教授）

布川喬

(昭和 46 年 2 月 23 日受付)

原発性甲状腺機能異常症における血漿 HGH，ACTH，LH および 11-OHCS の insulin または arginine に対する反応様相から，てれらホルモン分泌の下垂体予備能を検討した。 その結果，機能六 進症, 低下症でも, 特に HGH ついで AGTH と LH の分泌能の低下傾向が示唆された. HGH で は, 甲状腺ホルモンの過剰または欠乏による中枢の $\mathrm{HGH}$ 分泌調節の二次的異常による可能性が, ACTH や LH については体内代謝速度の変化による可能性が，その原因として推定された.

\section{I）緒言}

甲状腺機能異常症において下垂体前葉の予備能がどの樣な態度を示すかについては, 現在の所なお一定し た知見が得られていない.

著者は，乙の種の疾患例における血漿成長ホルモン (human growth hormone, 以下 HGH と略す)， 副腎皮質刺激ホルモン（adrenocorticotropic hormone, 以下 ACTH と略す）および黄体化ホルモン (luteinizing hormone, 以下 LH と略す)を radioimmunoassay によりそれぞれ測定し, insulin 負荷等に 対する反応の様相から，てれらホルモン分泌に関する下垂体の予備能を検討した。ささら著者は，一部の症 例については治療前後における下垂体予備能をも比較検討し, 甲状腺機能異常症の際の下垂体レベルでの各 種tropic hormone の動態を検討した. 以下その成績を報告する.

\section{II）実験対象並に実験方法}

対象とした甲状腺機能異常症例 (Table 1, 2, 3) は, 甲状腺機能元進症および甲状腺機能低下症である. 甲状腺機能六進症は男子18例（うち周期性四肢麻盘合併例 6 例），女子 9 例，計 27 例であり，機能低下症は 男子 1 例, 女子 9 例, 計 10 例である. これらの甲状腺機能異常症例は, 臨床症状以外に, 基礎代謝率 (BMR), 甲状腺 ${ }^{131} \mathrm{I}$ 摂取率，および Triosorb 試験等の成績から診断されたものである.

うち，機能元進症の 9 例では ${ }^{131} \mathrm{I}$ 治療ないしは methylmercaptoimidazole 投与により，また機能低下 症の 4 例では甲状腺末補充療法により, それぞれ臨床症状ないし検査成績の改善がみられた際にも, 治療前 と同様に下垂体予備能の検索を行なつた。 さらに機能立進症の 3 例では治療開始前に $\beta$-blocker である propranolol (Inderal) の投与を近ない，その影響について検討し，また機能圥進症の 2 例および低下症の 1 例 では, ${ }^{131} \mathrm{I}$ 標識 $\mathrm{HGH}$ を静注投与して, $\mathrm{HGH}$ の血中半減期の検索をも行なつた.

ホルモンの測定は以下の如く行なつた。即ち血漿 $\mathrm{HGH}^{1)}, \mathrm{ACTH}^{2)}$ およ゙ $\mathrm{LH}^{3)}$ は，いずれも dextran coated charcoal を用いた出村らの radioimmunoassay 法により，また 11-hydroxycorticosteroids (以下 11-OHCS と略す) は，De Moor ら り測定した。

下垂体予備能の検索は次の方法に従つた。 まず insulin 負荷試験では，早期空腹時に regular insulin 
$0.1 \mathrm{U} / \mathrm{kg}$ を 1 回で静注し，注射前および注射後20，30，45，60，90，120分にそれぞれ採血して血漿中 HGH， ACTH，LH，11-OHCS の測定に供した. Arginine 負荷試験には，0.5g/kg (arginine monochloride を $10 \%$ 溶液として生理食塩水に溶解したもの）を30分間にわたり点滴静注し，点滴開始前と点滴開始後 $30 ， 60$, 90，120分に採血し，血漿 HGH を測定した.

${ }^{131} \mathrm{I}-\mathrm{HGH}$ の血中半減期の測定は, 次の様に行なつた. 即ちとト HGH (Dr. Wilhelmi 提供によるもの, No. HS 1064G) を Greenwood and Hunter ${ }^{5)}$ の方法により ${ }^{131}$ I で標識し, Sephadex G 100 column で純 化した。早朝空腹時に，その約 $0.1 \mu \mathrm{g}(200 \mathrm{mc} / \mathrm{mg})$ を 1 回で急速に静注し，注射後 $2,5,10,20,30,60$, 90，120分にそれぞれ採血した。 ついでこの血漿 $1 \mathrm{ml}$ に dextran coated charcoal 液（ $0.5 \%$ dextran 水 溶液と $5 \%$ charcoal 液を等量に混じたもの） $1 \mathrm{ml}$ を加えて15分間振盪後，1時間室温に放置し遠心分離し た. この様にして charcoal に吸着させることにより damaged fraction から free ${ }^{131} \mathrm{I}-\mathrm{HGH}$ を分離し, そのカウント数を片対数グラフにプロットし, その減衰曲線から血中半減期を求めた.

\section{III）実 験 成 績}

\section{A] 甲状腺機能異常症例における血獎 HGH について \\ 1) Insulin 負荷に対する血獎 HGH の反応 \\ a) 機能六進症}

Fig. 1 亿示す如く，周期性四肢麻症合併例 6 例を含む機能六進症20例における成績では，血糖は insulin 静注後, 前值の平均 $71 \mathrm{mg} / \mathrm{dl}$ から全例 $50 \%$ 以下に低下して, 20 分後に最低值の平均 $33 \mathrm{mg} / \mathrm{dll}$ に達し, 90 〜120分後に前値に復した. 即ち機能元進症でもほぼ正常の insulin 感受性を示した. ての際の血漿 HGH は, 前值は平均 $2.3 \mathrm{~m} \mu \mathrm{g} / \mathrm{ml}$ と正常範囲 $(0 \sim 6 \mathrm{~m} \mu \mathrm{g} / \mathrm{ml})$ にあつたが, 反応は平均して60分後で最高で, 平 均值は $14.0 \mathrm{~m} \mu \mathrm{g} / \mathrm{ml}$ と，正常者 40 例の平均 $27.3 \mathrm{~m} \mu \mathrm{g} / \mathrm{ml}$ に比し明らかに低下していた.

周期性四肢麻痷を伴つた 6 症例においても Fig. 2 の如く同様の検索を加えたが，乙の場合には insulin に対する血糖の感受性に異常がみられた例が 3 例あつた，即ち 6 例中 1 例では $0.1 \mathrm{U} / \mathrm{kg}$ の insulin 静注で 血糖が著明にかつ 120 分にわたり低下し続けた，他の 2 例では, insulin 負荷後, 低血糖に引き続いて反応

Fig. 1. Responses of plasma HGH to insulininduced hypoglycemia in 20 cases with hyperthyroidism

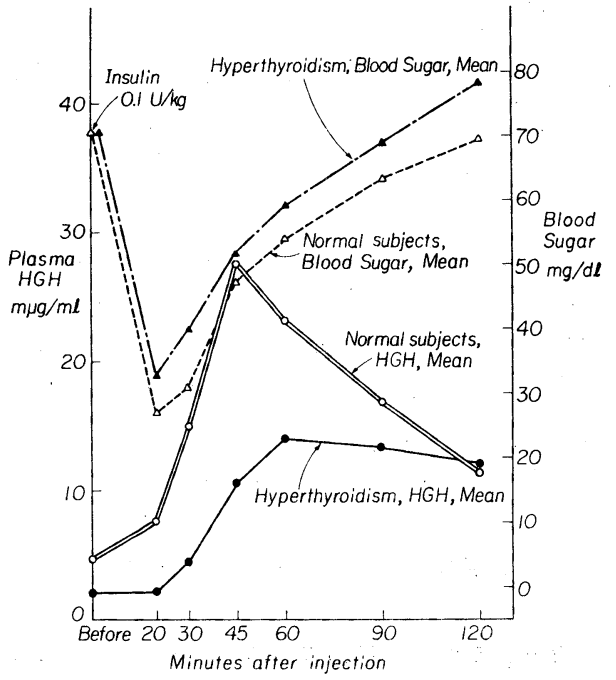

Fig. 2. Responses of plasma $\mathrm{HGH}$ to insulininduced hypoglycemia in 6 cases with hyperthyroidism with periodic paralysis

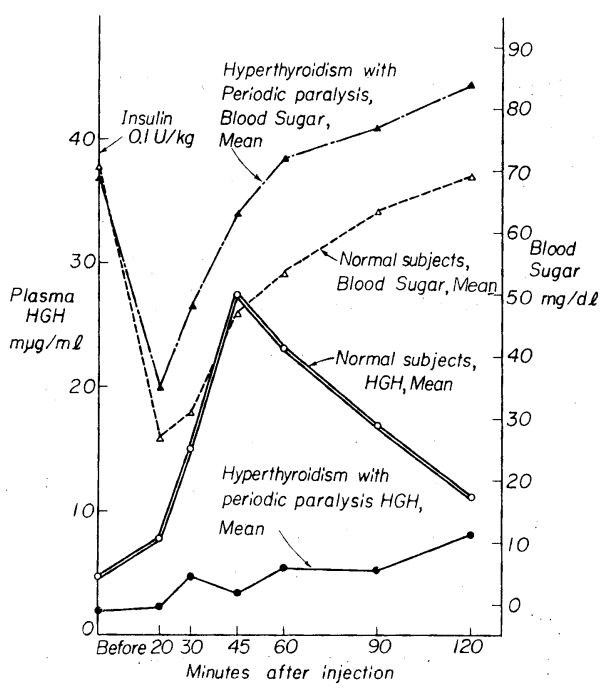


性の過血糖がみられた。全症例 6 例の平均では，血糖は insulin により約 $50 \%$ の低下を示した。乙の際の 血墏 $\mathrm{HGH}$ の平均增加反応は $8.3 \mathrm{~m} \mu \mathrm{g} / \mathrm{ml}$ と一般の甲状腺機能六進症における反応に比し, さらに減弱し ていた. ただしてのうち, insulin 感受性に異常を示した上述の 3 例と, 他の 3 例との間には, 血漿 HGH の反応には特に明らかな差は認められず，いずれも低下していた。

\section{b) 機能低下症 (Fig. 3)}

機能低下症 8 例においては, insulin 負荷後の血糖低下の程度は正常者わよび機能六進症における場合よ りも軽度で, 血糖值の回復もまた幾分緩徐であつた。 血墏 HGH は, 前值および insulin 負荷時の反応 值とも低下しており，検查の経過中全く検出されな い例も見られた。前值は平均 $0.3 \mathrm{~m} \mu \mathrm{g} / \mathrm{ml}$ で, 反応 は平均して注射後 30 分で最大で, その平均值は 2.8 $\mathrm{m} \mu \mathrm{g} / \mathrm{ml}$ であり, 正常者の平均 $27.3 \mathrm{~m} \mu \mathrm{g} / \mathrm{ml}$ 亿比 較して著明に低下していた。

2) Arginine 負荷に対する血獎 HGH の反応

a) 機能進症 (Fig. 4)

機能六進症 8 例では, 血漿 $\mathrm{HGH}$ の前值は平均 $3 \mathrm{~m} \mu \mathrm{g} / \mathrm{ml}$ と正常であつたが, arginine に対する反 応は，insulin 負荷時と同様に，大部分の例で正常 以下に止まつた. 即ち, 一般に30分で最大反応を示 したが，その值は平均 $6.0 \mathrm{~m} \mu \mathrm{g} / \mathrm{ml}$ に過ぎず，正常 者の平均 $30.2 \mathrm{~m} \mu \mathrm{g} / \mathrm{ml}$ に比し反応は明らかに減弱 していた.

\section{b) 機能低下症 (Fig. 5)}

機能低下症 8 例における血獎 $\mathrm{HGH}$ の前值は平 均 $1.3 \mathrm{~m} \mu \mathrm{g} / \mathrm{ml}$ と正常であつたが, arginine 負荷時

Fig. 4. Responses of plasma HGH to arginine infusion in 8 cases with hyperthyroidism

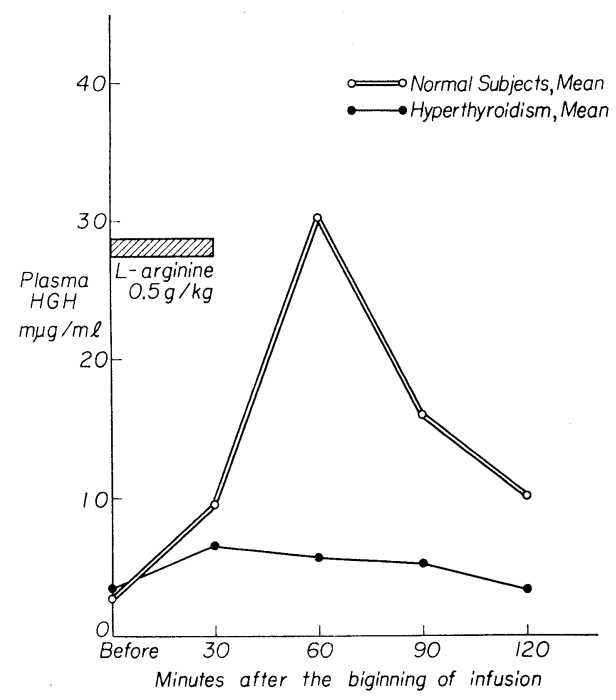

Fig. 3. Responses of plasma HGH to insulininduced hypoglycemia in 8 cases with hypothyroidism

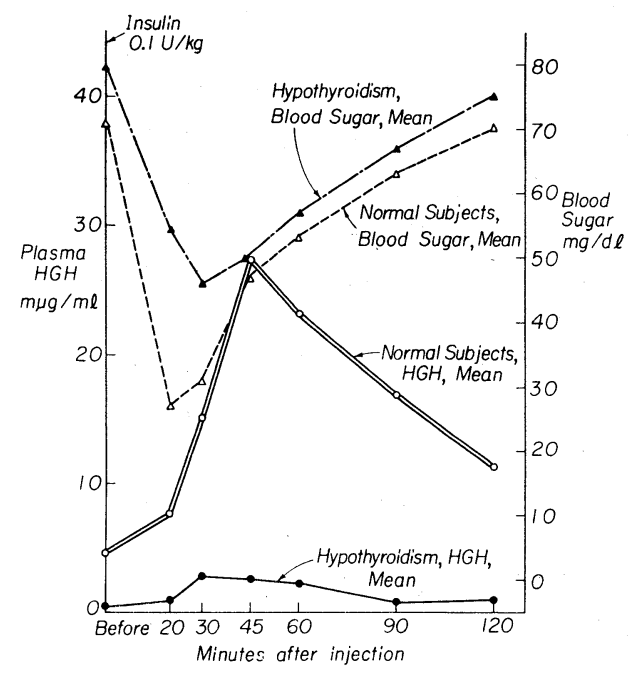

Fig. 5. Responses of plasma $\mathrm{HGH}$ to arginine infusion in 8 cases with hypothyroidism

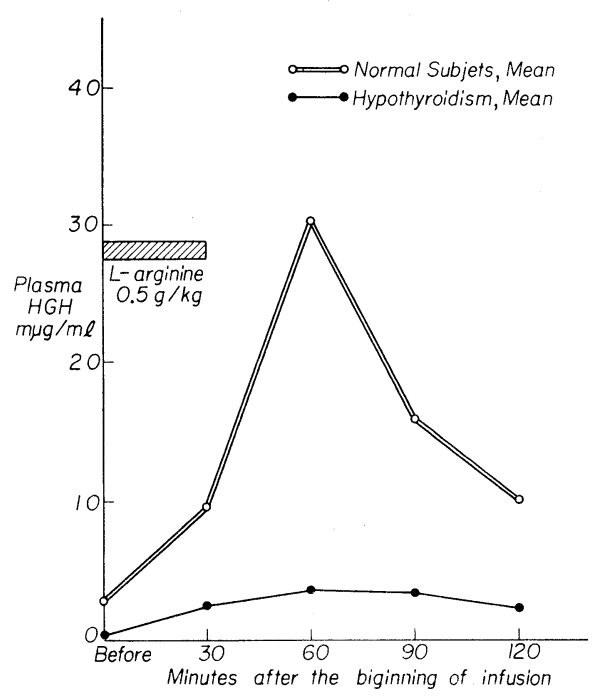


の反応は, insulin に対すると同様に, 著明に低下していた，即ち，最高值は平均 $3.7 \mathrm{~m} \mu \mathrm{g} / \mathrm{ml}$ に過ぎず, 全例で反応の減弱が認められた。

\section{3 ）甲状腺機能六進症における HGH 分泌能に対する $\beta$-blocker の影響}

Fig. 6 に示す如く, 機能六進症 3 例について, insulin 負荷に対する血漿 HGH の反応態度を, Inderal 毎日 $30 \mathrm{mg}$ を 2 週間経口投与して頻脈, 動悸等が改善された時期と投与前とで比較検討した. その結果で は，Inderal 投与中に実施した insulin に対する反応は，Inderal 投与前に比し，3例中 1 例で亢進，1例 では不変，1例で低下しており，一定の傾向は得られなかつた。 ての他に, Inderal 投与中にのみ負荷試験 を行なつた例が 2 例あつたが, この 2 例を含めた 5 例において, Inderal 投与中に測定した insulin に対す る最大反応值の平均は $11.9 \mathrm{~m} \mu \mathrm{g} / \mathrm{ml}$ に止まつた。 即ち，Inderal 投与により insulin 低血糖に対する血漿 $\mathrm{HGH}$ の増加反応に一定の変化が見られるという成績は得られなかつた.

また Fig. 7 の如く, Inderal 6mg を insulin と同時に急速に静注負荷した 1 例では, Inderal 併用前に くらべて HGH の上昇反応が幾分増加したかに見られたが， Inderal 併用時のみ insulin 負荷試験をした 他の 2 例を含めた 3 例の最大反応の平均值は $10.3 \mathrm{~m} \mu \mathrm{g} / \mathrm{ml}$ であり，20例の機能立進症の insulin 負荷試験 に対する最大反応值が平均 $14.0 \mathrm{~m} \mu \mathrm{g} / \mathrm{ml}$ であつた（Fig. 1) のに比し，むしろ低下していた。

\section{4) HGH の血中半隇期 (Fig. 8)}

前述の方法で片対数グラフに free ${ }^{131} \mathrm{I}-\mathrm{HGH}$ のカウント数 $(\mathrm{cpm})$ を経時的にプロットするととにより 得られた減衰曲線は，主に拡散によると考えられる急速な減衰を示す第 1 相と，代謝による血中からの消失 を表わすと考えられる比較的緩徐な第 2 相との 2 つの compartment に分けられるととを認めた. とのよう にして検討した結果によれば，正常者 2 例中 1 例では，第 1 相の半減期が 5 分，第 2 相の半減期が74分，ま た他の 1 例では，第 1 相の半減期が 8 分，第 2 相の半減期が 62 分であり，代謝速度を表わすと考えられる第 2 相の半減期は， 2 例の平均で68分であつた.

これに対して機能進症 2 例中の 1 例では，第 1 相の半減期が 4 分，第 2 相のそれは62分，また他の 1 例 では第 1 相の半減期が 7 分, 第 2 相のそれは 56 分であり, 第 2 相の平均は59分で, 正常に比し約 10 分の短縮 が認められた。一方，機能低下症の 1 例における検索では, 第 1 相の半減期が 9 分, 第 2 相のそれは 101 分

Fig. 6. Effect of oral administration of beta adrenergic blocker on plasma $\mathrm{HGH}$ responses to insulin-induced hypoglycemia in cases with hyperthyroidism
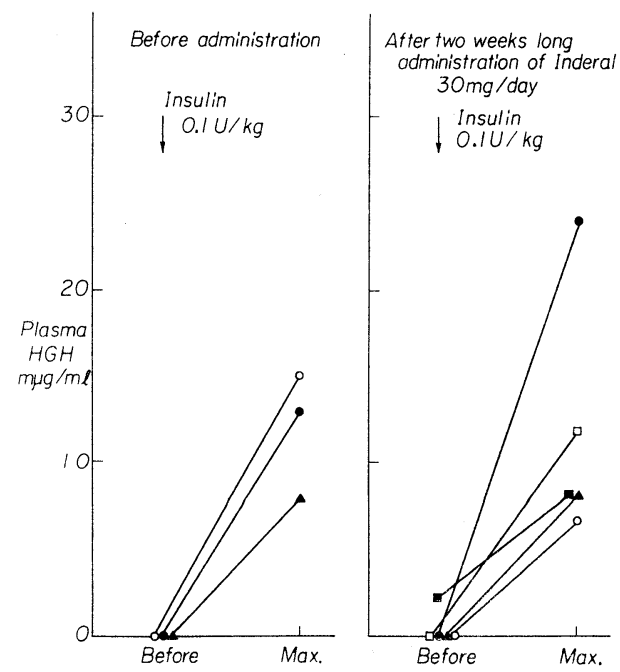

Fig. 7. Effect of single intravenous administration of beta adrenergic blocker on plasma HGH responses to insulininduced hypoglycemia in cases with hyperthyroidism

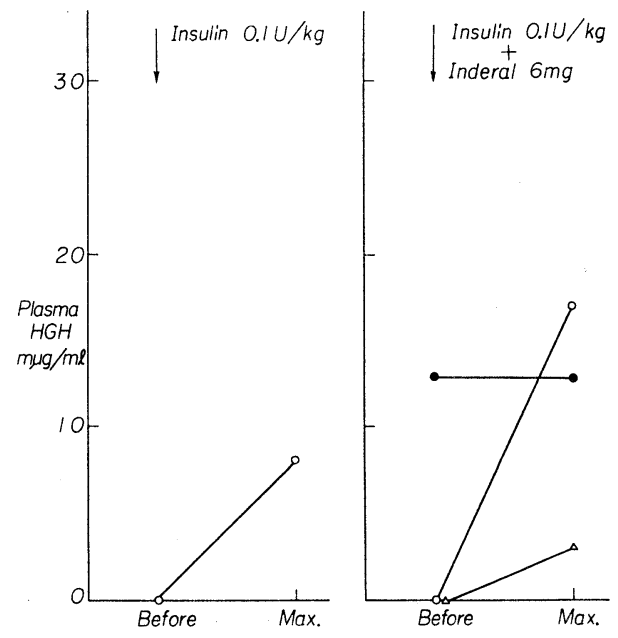


であり，正常者の場合に比し著明に遅延していることが認められた。

\section{5 ）甲状腺機能異常症例における血墏 HGH の各種負荷試験に対する反応の甲状腺治療後の変化}

\section{a) Insulin 負荷試験}

Fig. 9 亿示す如く，機能六進症 6 例の治療後にお ける insulin 低血糖に対する血漿 HGH の反応は, 前值は平均 $1.4 \mathrm{~m} \mu \mathrm{g} / \mathrm{ml}$ と正常であつたが，反応は 平均して 45 分で最高で，その值は $34.2 \mathrm{~m} \mu \mathrm{g} / \mathrm{ml}$ で あつた．即ち，治療開始前の值に比べては勿論，正 常者の平均 $27.3 \mathrm{~m} \mu \mathrm{g} / \mathrm{ml}$ 亿比しても，むしろ高值で あつた。なお，血糖は前值の平均 $82 \mathrm{mg} / \mathrm{dl}$ 汃全 例で insulin により50\%以下に低下して，20分後に 最低值の平均 $34 \mathrm{mg} / \mathrm{d} 1$ 亿達し, 回復も全く正常の パターンを示した.

一方，Fig. 10 の如く，機能低下症治療後の例 3 例では, 血糖は前值の平均 $97 \mathrm{mg} / \mathrm{dl}$ から 30 分後に 最低值の平均 $44 \mathrm{mg} / \mathrm{dl}$ に達しており, 回復も幾分 緩徐で，治療前と大差は見られなかつた。血漿 $\mathrm{HGH}$ は, 前值は平均 $1.8 \mathrm{~m} \mu \mathrm{g} / \mathrm{ml}$ と正常であつた が, 反応は 90 分で最高で, その值は平均 $13.3 \mathrm{~m} \mu \mathrm{g} / \mathrm{ml}$ であつた. 即ち, 治療前の最高值の平均 $2.8 \mathrm{~m} \mu \mathrm{g} / \mathrm{ml}$ に比しかなり上昇していたが，なお正常反応を示す には至つていなかつた。

\section{b) Arginine 負荷試験}

Fig. 11 亿示す如く, 機能六進症治療後の例 4 例

Fig. 9, Responses of plasma HGH to insulininduced hypoglycemia in 6 cases with hyperthyroidism after treatment

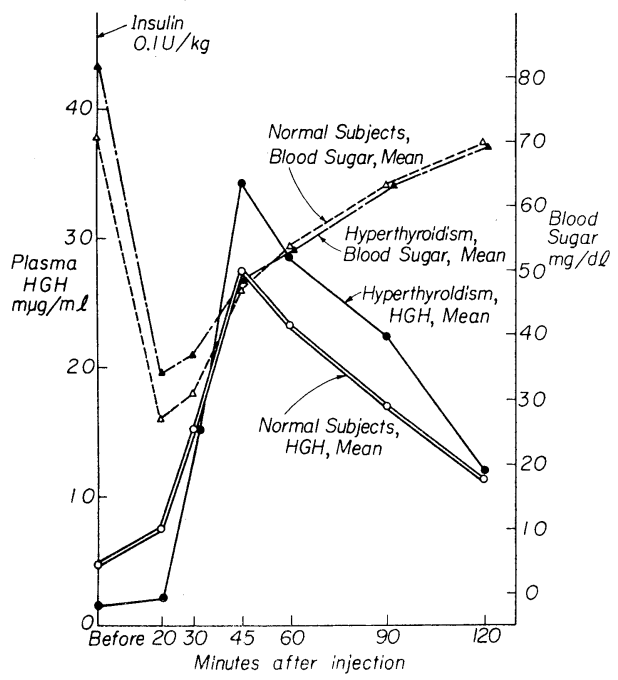

Fig. 8. Disappearance rate of dextran coated charcoal precipitable radioactivity from circulating plasma after intravenous administration of ${ }^{131}$ I-labelled HGH

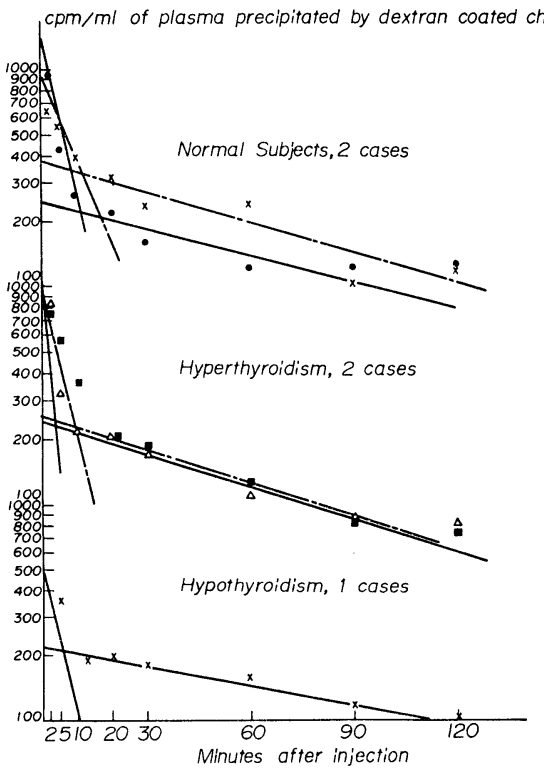

Fig. 10. Responses of plasma HGH to insulininduced hypoglycemia in 3 cases with hypothyroidism after treatment

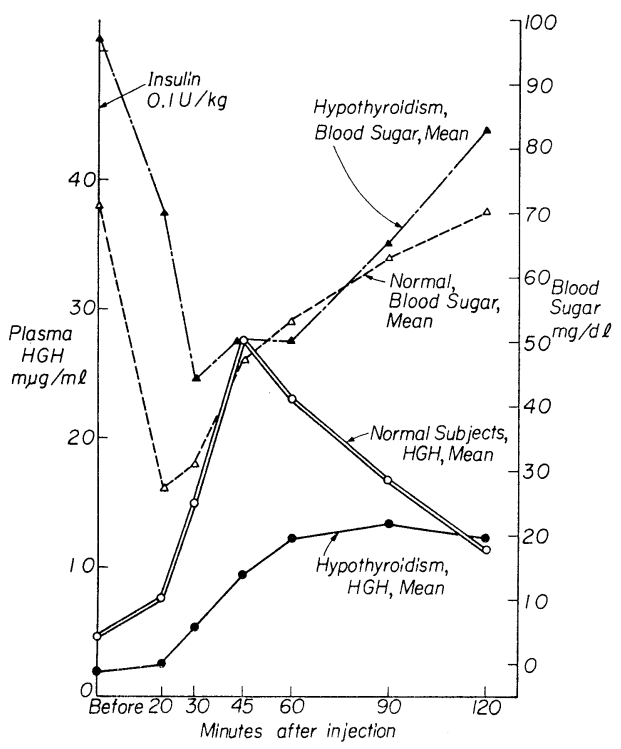


における血漿 HGH の arginine に対する反応は，前值は平均 $1.3 \mathrm{~m} \mu \mathrm{g} / \mathrm{ml}$ と正常で，反応は平均して 60 分後に最高で, その平均值は $26.5 \mathrm{~m} \mu \mathrm{g} / \mathrm{ml}$ であり, 正常域に復軋していた。

一方, Fig. 12 の如く, 機能低下症治療後の例 3 例では, 前值は平均 $1.9 \mathrm{~m} \mu \mathrm{g} / \mathrm{ml}$ と正常で, 反応は 60 分 で最高で，その值は平均して $9.9 \mathrm{~m} \mu \mathrm{g} / \mathrm{ml}$ であつた。 即ち治療前に比して明らかに上昇していたが，なお正 常反応を示すには至らなかつた。

Fig. 11. Responses of plasma HGH to arginine infusion in 4 cases with hyperthyroidism after treatment

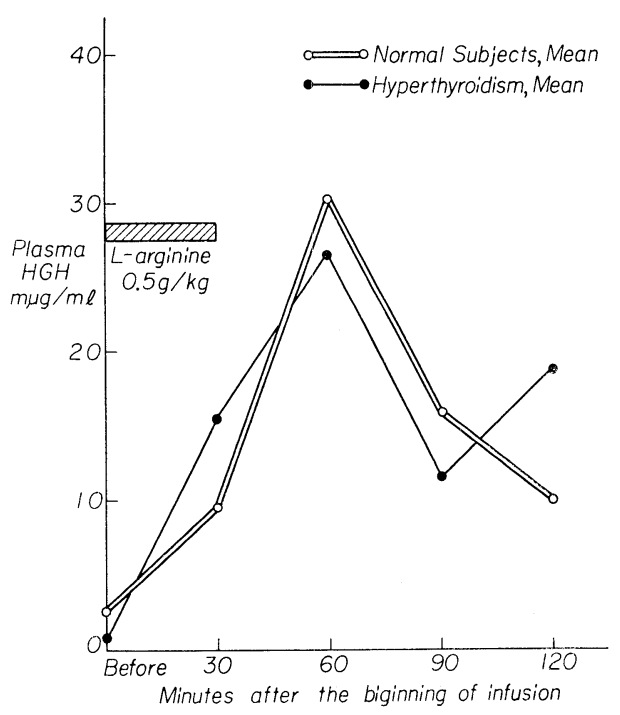

Fig. 12. Responses of plasma HGH to arginine infusion in 3 cases with hypothyroidism after treatment

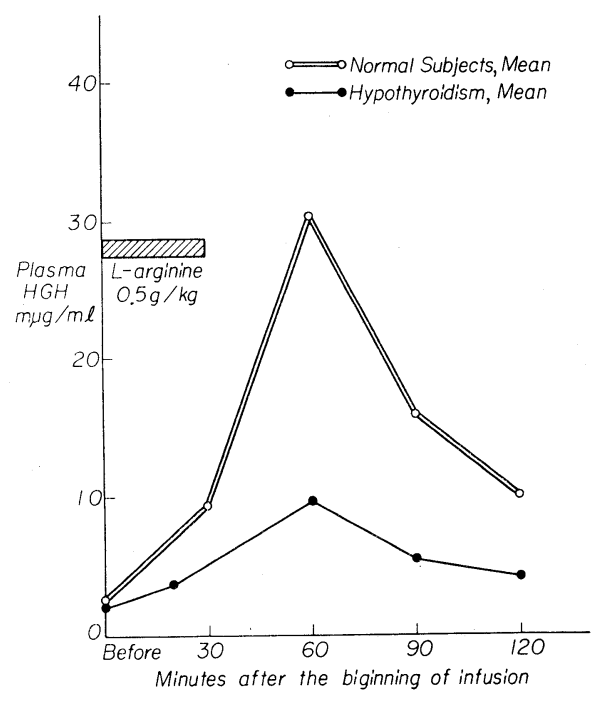

B）甲状腺機能異常症例における血獎 AGTH および血墏 11-OHCS について

1) 甲状腺機能異常症例における血墏 ACTH の insulin 負荷に対する反応

a) 機能六進症 (Fig. 13)

機能六進症17例における insulin 負荷時の血漿 ACTH は，前值は平均 $56 \mu \mu \mathrm{g} / \mathrm{ml}$ で正常者 $(20 \sim 80 \mu \mu \mathrm{g} /$ $\mathrm{ml})$ の平均 $42 \mu \mu \mathrm{g} / \mathrm{ml}$ 亿比し幾分高值を示したが, insulin 低血糖に対する最高反応值は平均 $142 \mu \mu \mathrm{g} / \mathrm{ml}$ であり, 正常者の平均 $181 \mu \mu \mathrm{g} / \mathrm{ml}$ に比し，反応の減弱傾向が示唆された。

b) 機能低下症 (Fig. 13)

機能低下症 7 例では, 前值は平均 $27 \mu \mu \mathrm{g} / \mathrm{ml}$ とほぼ正常であつたが, insulin に対する反応は平均 $90 \mu \mu \mathrm{g} /$ $\mathrm{ml}$ と減弱していた.

\section{2 ）甲状腺機能異常症の治療後における血獎 ACTH の insulin 負荷に対する反応}

甲状腺機能異常症治療後の症例における insulin 亿対する血漿 AGTH の反応は Fig. 14 の如くであつ た. 即ち機能充進症治療後の症例 5 例の血漿 ACTH の前值は平均 $61 \mu \mu \mathrm{g} / \mathrm{ml}$ で正常範囲にあり, insulin 低血糖に対する反応も平均 $219 \mu \mu \mathrm{g} / \mathrm{ml}$ に達し，正常範罒の上昇反応か認められた。即ち治療により下垂体 ACTH 分泌子備能の回復しているととが認められた。一方, 機能低下症治療後の 3 例では, 血漿 AGTH の前值は平均 $47 \mu \mu \mathrm{g} / \mathrm{ml}$ とほぽ正常で, また insulin 低血糖に対する反応は, 最大反応の平均が $155 \mu \mu \mathrm{g} /$ $\mathrm{ml}$ であり，治療前に比べれば反応の回復が認められた。

3 ）甲状腺機能異常症における血墏 11-OHCS の insulin 低血糖に対する反応

a) 機能六進症 (Fig. 15) 
Fig. 13. Maximal responses of plasma ACTH to insulin-induced hypoglycemia in patients with hyper- and hypothyroidism

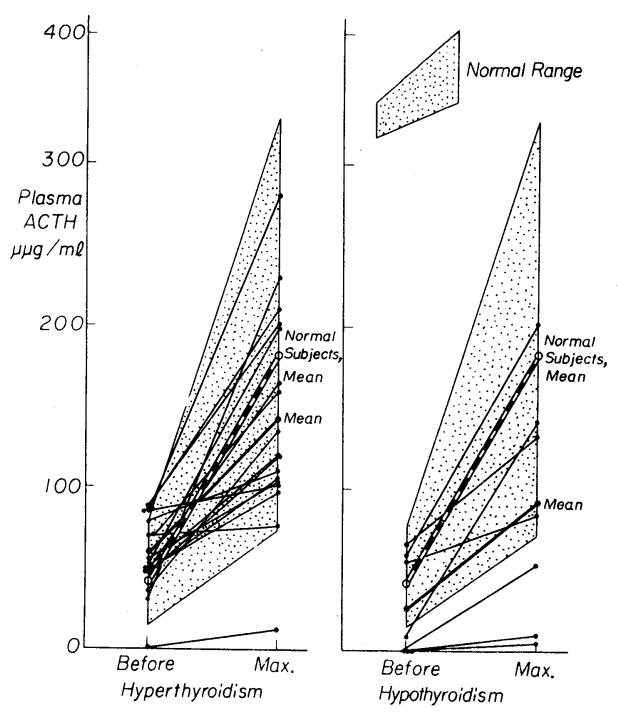

Fig. 15. Maximal responses of plasma 11-OHCS to insulin-induced hypoglocemia in patients with hyper- and hypothyroidism

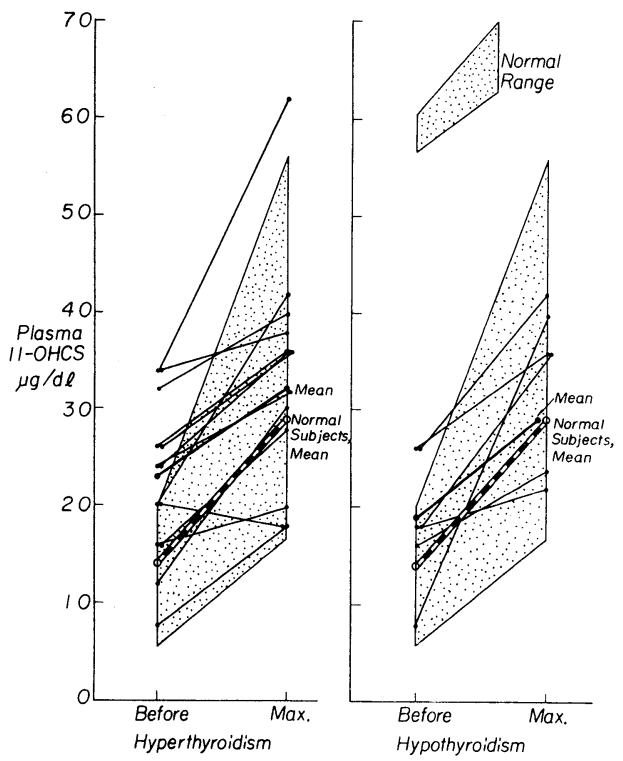

Fig. 14. Maximal responses of plasma ACTH to insulin-induced hypoglycemia after treatment of hyper- and hypothyroidism

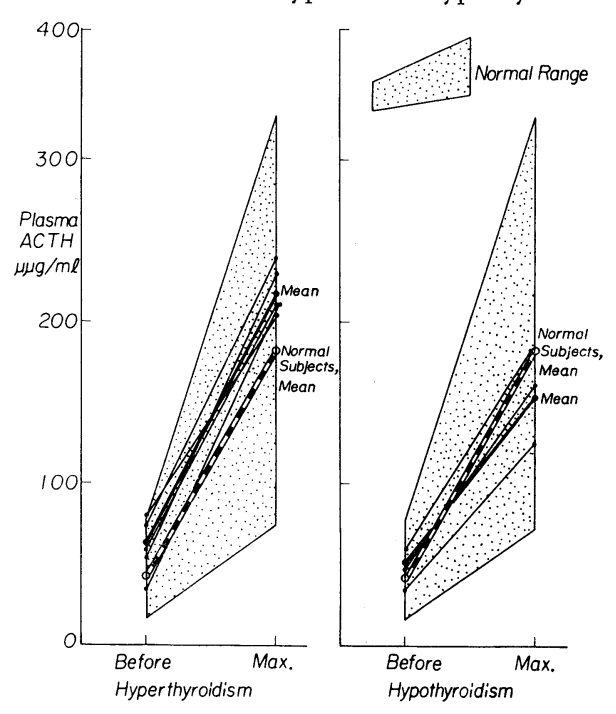

Fig. 16. Maximal responses of plasma 11-OHCS to insulin-induced hypoglycemia after treatmenti of hyper-and hypothyroidism

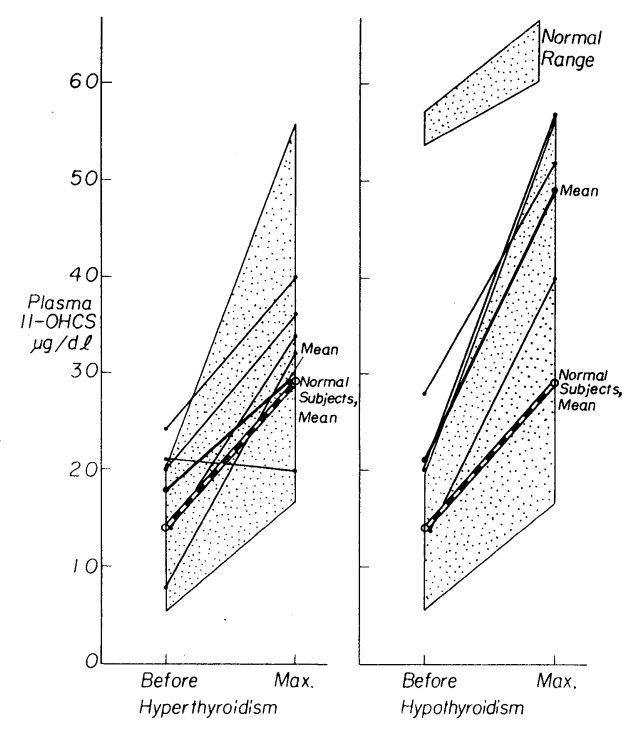

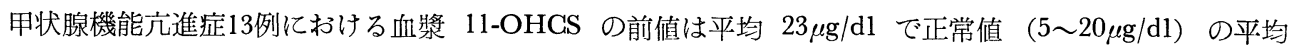
$14 \mu \mathrm{g} / \mathrm{dl}$ に比し幾分高值を示したが，insulin 低血糖に対する反応は，増分でみて，正常者における $15 \mu \mathrm{g} / \mathrm{dl}$ に対し機能立進症では $9 \mu \mathrm{g} / \mathrm{dl}$ であり, 反応の減弱が示唆された. 
b) 機能低下症 (Fig. 15)

機能低下症 6 例では，血漿 11-OHCS の前值は平均 $19 \mu \mathrm{g} / \mathrm{dl}$ と正常平均より幾分高かつたが，insulin に対する反応は，増分として $10 \mu \mathrm{g} / \mathrm{dl}$ 亿止まり，機能京進症と同様に増加反応の減弱が示唆された.

\section{4 ) 甲状腺機能異常症治療後における血漿 11-OHCS の insulin 低血糖に対する反応}

甲状腺機能異常症の治療後の場合の血漿 11-OHCS は，Fig. 16 の如く，機能立進症治療例 5 例では，前 值は平均 $18 \mu \mathrm{g} / \mathrm{d} 1$ と正常平均に近づき，反応も治療前より改善し，正常平均に近づいた，一方，機能低下 症治療例 3 例では, 前值は平均 $21 \mu \mathrm{g} / \mathrm{d} 1$ と幾分高值を示し, 反応としては増分が $26 \mu \mathrm{g} / \mathrm{d} 1$ であり, 治療前 の $10 \mu \mathrm{g} / \mathrm{dl}$ に比し著明に改善した.

\section{C) 甲状腺機能異常症例における血獎 LH について}

\section{1 ）血漿 I.H の insulin 低血糖に対する反応}

a) 機能六進症 (Fig. 17)

機能充進症15例では, 血漿 LH の前值は平均 $22 \mu \mathrm{g} / \mathrm{dl}$ でほぼ正常範囲 $(8 \sim 40 \mu \mathrm{g} / \mathrm{dl})$ にあつたが, insulin 低血糖に対する最大反応は平均 $39 \mu \mathrm{g} / \mathrm{dl}$ と正常者の平均 $61 \mu \mathrm{g} / \mathrm{dl}$ に比し減弱していた.

b) 機能低下症 (Fig. 17)

機能低下症 6 例では，血漿 LH の前值は平均 $17 \mu \mathrm{g} / \mathrm{dl}$ と正常平均より低く, insulin 低血糖に対する最 大反応值も平均 $26 \mu \mathrm{g} / \mathrm{dl}$ で, 反応は明らかに減弱していた.

\section{2 ) 甲状腺機能異常症の治療後における血漿 LH の insulin 低血糖に対する反応}

甲状腺機能異常症の治療後における血漿 LH の検索成績は，次の様であつた (Fig. 18). 即ち, 機能元進 症 5 例では，前值は平均 $20 \mu \mathrm{g} / \mathrm{dl}$ と正常よりやや低值であつたが，insulin 低血糖に対する血漿 LH の反 応は最大反応值が平均 $43 \mu \mathrm{g} / \mathrm{dl}$ と治療前に比して増加していた。 また機能低下症治療例 3 例では, 前值は 平均 $14 \mu \mathrm{g} / \mathrm{dl}$ とやや低值であつたが, insulin 低血糖に対する最大反応值は平均 $37 \mu \mathrm{g} / \mathrm{dl}$ に達し, 機能立 進症と同様，治療による下垂体 LH 分泌子備能の回復が認められた.

Fig. 17. Maximal responses of plasma LH to insulin-induced hypoglycemia in patients with hyper- and hypothyroidism

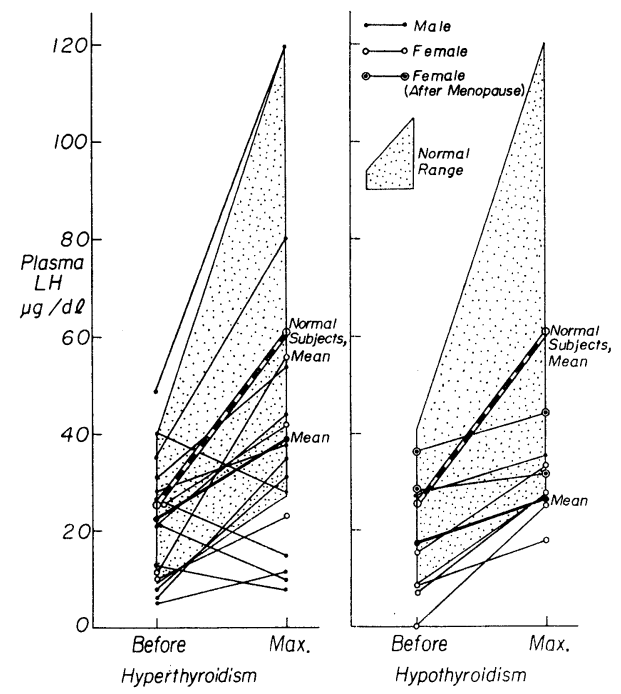

IV) 考
Fig. 18. Maximal responses of plasma $\mathrm{LH}$ to insulin-induced hypoglycemia after treatment of hyper- and hypothyroidism

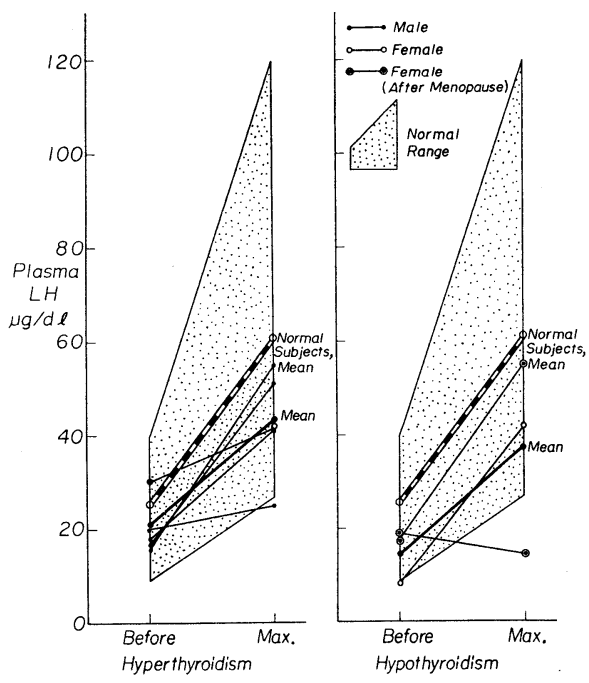

察

著者の成績によれば，甲状腺機能異常症においては insulin 負荷および arginine 負荷に対する血漿 HGH 
の増加反応は, どちらも正常者の場合に比し明らかに減弱していた。

まず甲状腺機能充進症における insulin 負荷時の成績について考察すると, 血糖は $0.1 \mathrm{U} / \mathrm{kg}$ の insulin の静注により50\%以下に低下しており，乙の点問題はない．Insulin 低血糖に対する血漿 HGH の反応に ついては，てれ迄 Burgess $ら^{6)}$, Takeuchi $ら^{7)}$, 著者と同様に, 甲状腺機能六進症においては, 反応が減 弱しているととを報告しているが，一方，岡田 ${ }^{8)}$, Katz $ら^{9)}$, Rosenfeld ら $^{10)}$ のように正常人と大差がない とする報告も見られる．ただし上記の報告はいずれも10例以内の比較的少数例を対象とした場合の報告であ り, 対象例数の差, 正常範囲の定め方等によつて成績に差方出て来た可能性も考えられる. 著者の対象とし た24例中， 2,3 の症例では正常高值の反応を示したが, 約半数では正常以下゙の反応を示していた. てれら を平均すると，明らかに反応は低下しており，かつてれは insulin 負荷時ばかりでなく, arginine 負荷時 にも同様であつた。

甲状腺機能亢進症の重症度と $\mathrm{HGH}$ 分泌機能との間に相関関係が存在するととは当然予想される所であ り, 岡田 ${ }^{8)}$ によれば, 機能立進症 9 例の血中 HGH の insulin に対する増加反応は健常者と変りがなかつ たが，ただ機能え進の状態で 1 年以上放置されていた重症の 1 例では明らが低下していたという。しかし ての点に関して著者の検索したとてろでは (Table 1,2,3), 否定的な成績が得られた. 即ち BMR, ${ }^{131}$ I 甲 状腺摂取率，Triosorb 試験のそれぞれの成績と insulin または arginine に対する HGH の反応度との間 には，個々の症例で何らの相関もみられなかつた。

著者の対象とした甲状腺機能六進症のうち, 周期性四肢麻痺を伴つた例とてれを伴わなかつた例との間で 甲状腺機能元進の程度や他の臨床所見に差はなかつた．ただ周期性四肢麻痺を伴つた例では，てれを伴わな かつた例に比較して insulin に対する HGH の反応がさらに低下していたが，その意義は不明である．ち なみに紫芝ら ${ }^{11)}$ は, 周期性四肢麻瘦を伴つた機能充進症患者では麻瘦発作に先立つて hyperinsulinism が みられたが，血漿 HGH の baseline はほぼ正常範囲にあつたと報告している。

次に arginine に対する血墏 HGH の反応について，Strauch ら ${ }^{12)}$ は機能充進症で arginine に対する HGH の反応は正常であつたと述べているが, 著者の成績では多数例において, 明らか沉反応が減弱してお り, insulin 低血糖に対すると同様な結果であつた，即ち，本症では両刺激に対して HGH の放出あるい は分泌の障害が存在するととは間違いないと考えられる.

てのように甲状腺機能充進症にわいては下垂体 HGH 分泌予備能が低下していると考光られるが，その 機序について考察すると主なものが3つあげられる. 第1亿, 最近, HGH 分蜜に adrenergic mechanism

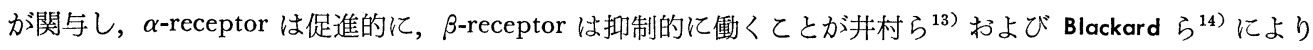
指摘されている. 例えば褐色細胞腫では HGH 分泌が低下しており, $\beta$-blocker 使用時や腫瘍摘出後に insulin 飞対する HGH の反応が回復すると報告 ${ }^{15)}$ されている. 甲状腺機能六進症においては, catecholamine の代謝, 排泄の様相に特に異常がないとされている ${ }^{16)}$ が, $\beta$-receptor 優位の可能性は残されて抢り, てれにより HGH の反応が抑制されているという機序を完全には否定できない，そてで著者は，本症例に $\beta$-blocker である Inderal を連続経口投与した場合や，一回静注した場合において，insulin 低血糖に対す る HGH の反応に差がみられないか否かを検討したわけである，とてろがその結果では，Inderal 使用前

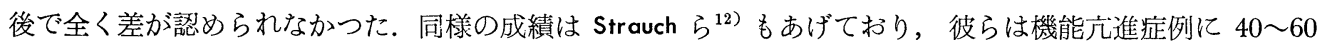
mg の propranolol を $3 \sim 4$ 日間投与したが, arginine に対する HGH の反応に差は認められなかつた と報告している，乙れらの成績を考慮すると，甲状腺機能元進症における HGH 分泌障害が， $\beta$ 優位にも とづくという可能性はかなり否定的であると思われる.

第 2 の機序として, 甲状腺機能六進症においては HGH の代謝が変化していて，てれによつて HGH の 分泌障害が生じている可能性が考えられる，具体的には，HGH の代謝の促進の結果，血中ホルモン測定成 績において反応が見かけ上減弱している可能性や, growth hormone releasing factor の feedback 機序を 介して下垂体から長期間にわたりたえず HGH の分泌が起てつた結果，insulin や arginine 等の分泌刺激 に対する反応性予備能が低下してきた可能性が示唆される。著者が ${ }^{131} \mathrm{I}-\mathrm{HGH}$ を静注して血中半減期を調べ 
たところでは，HGH の血中よりの消失は，2 compartments system に従つていると考えられるようであ る. 正常者 2 例の平均では ${ }^{131} \mathrm{I}-\mathrm{HGH}$ の血中半減期は，第 1 相 6 分 30 秒，第 2 相 68 分であつた. 文献上， ${ }^{131} \mathrm{I}-\mathrm{HGH}$ を静注してその血中半減期をしらべた Parker ら ${ }^{17)}$ は静注後 10〜100分の閔の一相性の減衰曲線 から17３4分（平均26分）と報告，また著者と同様に 2 compartments system を想定している Conti ら ${ }^{18)}$ は，第 1 相20分，第 2 相 273 分と報告している．また同しく Cameron ら ${ }^{19)}$ は，第 1 相が，11〜16分，第 2 相が104〜180分と報告している，乙れらの報告における成績の差は，damaged fraction の影響をどのよう に除いているか等の方法の違いによるものが大であろう. 著者の行なつた dextran coated charcoal 吸着法 は，各種下垂体ホルモンの radioimmunoassay において free と bound の分離に広く用いられている方法 で，簡単にまたほぼ完全に bound form および damaged fraction の影響を除くことができる，その結果， 上述の正常者の成績に対して 2 例の機能圥進症では, 第 2 相の半減期が正常者のそれに比し約 10 分短縮して いるととを認めた。 即ち, 上述の $\mathrm{HGH}$ 代謝に関する推定を否定するてとは出来ないにしても，わずか10 分の差で本症における明らかな $\mathrm{HGH}$ 分泌の低下をすべて説明するととはやはり無理と考えられ，他にも 原因を求めるととが必要ということになろう。

第 3 の機序として，本症においては元来 $\mathrm{HGH}$ の分泌調節機構に異常があるのではないかという可能性 があげられる. 例えば, 甲状腺機能立進症例では, 下垂体性 Cushing 症候群のようにもともと何らかの中 枢異常があり，その結果 insulin や arginine 等の分泌刺激を正常に感受しないという可能性があるが，て の点は否定的と考えられる. 即ち本症では, 著者の成績から明らかなように, ${ }^{131} \mathrm{I}$ 療法や抗甲状腺剤療法等 により，換言すれば，甲状腺ホルモン分泌の抑制によつて本症が治痛すると，HGH の反応は insulin，arginine のいずれに対しても正常化するてとが認められた. 従つて本症における HGH 分泌障害は, 甲状腺 ホルモン分泌増加の結果としてみられた二次的なものと考えるてともできる. 動物実験においても, Daughaday ${ }^{20)}$ はラットに thyroxine を投与すると，下垂体の甲状腺刺激ホルモン (thyroid stimulating hormone, 以下 TSH と略す) の濃度が減少するのみならず，同時に HGH の濃度も有意の減少を示したと述 ベているが，乙れも同じ考えを支持する成績といえよう. Burgess ら ${ }^{6)}$ は，正常者に triiodothyronine を投 与した結果，急性投与実験では特に HGH の反応に差を認めることができなかつたが，しかし慢性の甲状 腺ホルモンの上昇では，乙れが直接，間接に HGH 分泌に影響を与えているのであろうと述べている.

Vinik ら ${ }^{21)}$ は，甲状腺機能九進症ではブドウ糖負荷による血中 HGH の抑制が正常者に比べて軽度であつ たと報告している，彼は本症では，HGH 分泌の視床下部，下垂体における調節機構に異常があることを想 定して，それは慢性の代謝の元進や stress 状態にあるととによるものと考察している.

いずれにせよ，本症においては甲状腺ホルモンの増量の結果，二次的に細胞内の代謝に変化がもたらされ， 問脳，下垂体レベルまたは更により高位の中枢に異常が起てつて上述のような HGH 分泌の障害が招来さ れている可能性が，本症における $\mathrm{HGH}$ 分泌低下の主因としてあげられる．最近，本症では甲状腺ホルモ ン上昇の結果 feedback 機序により下垂体または血中 TSH が抑制されていることが明らかになつてきた が22), glucocorticoid の $\mathrm{HGH}^{23)}$ や $\mathrm{TSH}^{24)}$ の抑制効果から示唆されるように，各種 target hormone tropic hormone との feedback 機構の overlap により, thyroxine の増量が下垂体レベルで TSH ばか りでなく $\mathrm{HGH}$ や後述の AGTH 等の他の下垂体ホルモンを同時に抑制している可能性についても，一考 を要するであろう。しかし後述の機能低下症において, 逆に血中の $\mathrm{TSH}$ の著明な増加があり ${ }^{22)}$, 六進症と は TSH に関して全く逆の態度をとるにもかかわらず，同様に HGH，ACTH，LH 分泌関する下垂体予 備能の低下が見られるととから考察すると，ての見解は否定的であろう。

甲状腺機能低下症においても，著者の成績では，insulin 負荷および arginine 負荷の両刺激に対する HGH 分泌障害は明らかであつた。もつともその程度は光進症の場合より高度であつた。 ての事から甲状腺 ホルモンの過剩ばかりでなく欠乏のさいにも，HGH 分泌が㧕制されているととが明らかである。乙れ迄に も, Fink ${ }^{25)}$, Iwatsubo ${ }^{26)}$, 岡田 ${ }^{8)}$ は本症において insulin 刺激に対する HGH の反応の低下があり, 治

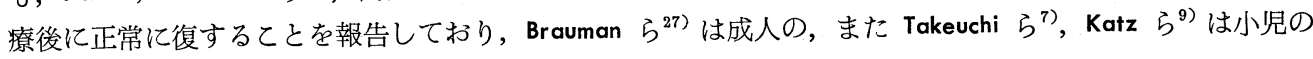


本症で，いずれも同様に insulin に対する HGH 分泌が低下しているととを報告している．動物実験でも， 甲状腺摘出ラットや抗甲状腺剤投与ラット ${ }^{28299}$ で下垂体 $\mathrm{HGH}$ 含量が低下し, 甲状腺ホルモンによる代償

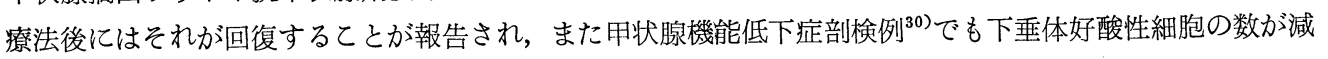
少しているてとも報告されている.

著者の成績によれば，本症における血漿中 ${ }^{131} \mathrm{I}-\mathrm{HGH}$ の半減期は， 1 例の検査で第 1 相は 9 分, 第 2 相 は101 分と正常の場合に比して明らかに遅延していた，即ち, 本症においては, 代謝速度の遅延により feedback 機序が作動して下垂体における HGH の合成および一日分泌量が低下している可能性も否定され ない.しかし本症における著明な $\mathrm{HGH}$ 分泌障害の主因は, 甲状腺機能六進症において論じたと同様に, 甲状腺ホルモンの欠乏が何らかの細胞内代謝異常を介して HGH 分泌予備能の低下を来した点にあると考 えられる. 機能低下症においても治療後に HGH の反応の回復が見られた点は，乙の可能性を強く支持す るものといえよう。いずれにせよ甲状腺ホルモンの過剩または欠乏は，共に HGH 分汼を抑制するものと 考えられた。

しかし HGH に関してての様な機序があげられるとしても, 後述する ACTH や LH に関しては, 必 らずしも HGH における如き著明な予備能の低下が認められておらず, この点, 甲状腺機能異常の影響は $\mathrm{HGH}$ 分泌に最も強く現われると考えられ, 問脳, 下垂体腫瘍等による二次的の下垂体機能の低下の際にも HGH 分泌障害が他に先がけて起こり易い点と考えあわせ興味深い.

次に甲状腺機能異常症における AGTH の態度について考察すると, 従来, 甲状腺機能充進症では, しば しば皮虐色素沈着が見られること，病理組織学的にしばしば副腎皮質に過形成像が見られるてと，あるいは 尿中, 血中 steroid, 特に前者が増加している成績 ${ }^{31)}$ などから, 下垂体 ACTH 分泌が方進しているととが 予測されている.

しかし最近まで ACTH の測定が困難であつたためか，本症における血中 ACTH 值を測定した報告は極 めて少ない，先ず， bioassay の成績では，Hilton ら ${ }^{32}$ は，6人の女性の甲状腺機能光進症患者の血漿中の ACTH 活性を測定した結果, 正常者の場合より明らかに増加しており，その值は $0.1 〜 0.5 \mathrm{~m} \mu / \mathrm{ml}$ であつた と推定している．乙れを $\mathrm{m} \mu / \mathrm{d} 1$ 亿換算すれば $10 \sim 50 \mathrm{~m} \mu / \mathrm{d} 1$ となる．しかしその後の報告を見ると，正常値 は $1 \mathrm{mu} / \mathrm{dl}$ 以下であるから，Hilton らの值はあまりに高いというととになる。なお，彼らは下垂体摘出犬 に 1-thyroxine, triiodothyronine あるいは TSH を投与しても cortisol 分泌増加作用が認められないの で, 甲状腺機能立進㭧者の血漿の cortisol 増加作用は AGTH そのものによると推定し, しかも治療後に これが正常化したと報告している. 次いで Givens ら ${ }^{33)}$ は，より正確な bioassay 法によつて甲状腺機能立 進症患者 5 例の血漿 ACTH 值を測定した結果, 牛前 6 時には $0.42 \sim 1.3 \mathrm{mu} / \mathrm{d} 1$ と正常値 $(0.09 \sim 0.38 \mathrm{mu} / \mathrm{d} 1)$ の $2 \sim 3$ 倍程度の高值を示したが, 午後 6 時には 1 例を除いて正常者と変りなく, 日内変動が大きかつたと 報告している.もつとも松倉 ${ }^{34}$ は, 正常者では血中 ACTH が検出されたのに, 甲状腺機能六進症10例中 9 例では検出不能であり，1例で $0.6 \mathrm{mu} / \mathrm{d} 1$ の正常值であつたと報告している.

1964年, Yalow ら ${ }^{35)}$ が，初めて血漿 AGTH の radioimmunoassay 法を発表して以来6年になるが，甲 状腺機能六進症患者の血漿 ACTH を radioimmunoassay 法によつて測定した報告は未だない様である. 著者の radioimmunoassay による成績によれば，甲状腺機能九進症17例に拐るる治療前の血漿 ACTH 值 は平均 $56 \mu \mu \mathrm{g} / \mathrm{ml}$ で, 正常例の平均 $42 \mu \mu \mathrm{g} / \mathrm{ml}$ 亿比へて幾分高值を示した. しかし insulin 低血糖に対す る血漿 ACTH の最高反応值は平均 $142 \mu \mu \mathrm{g} / \mathrm{ml}$ で, 正常対照例の平均 $181 \mu \mu \mathrm{g} / \mathrm{ml}$ に比べて反応の減弱傾 向が示唆された。 この際の血漿 11-OHCS は insulin 低血糖刺激に対して前值はやや高く, 最高反応值は 殆んぞ正常であつた，本症治療後の成績では，血漿 ACTH の前值は平均 $61 \mu \mu \mathrm{g} / \mathrm{ml}$ で治療前の平均值と ほぼ同じであつたが, insulin 低血糖に対する最高反応值は平均 $219 \mu \mu \mathrm{g} / \mathrm{ml}$ と治療前より上昇し, 正常対 照例以上の反応が認められた. 治療後の血漿 11-OHCS は, 前值および最高反応值とも正常対照例の場合と ほぼ同じ值が得られた。

本症においては尿中 17-OHCS および cortisol 分泌量は明らかに増加しているにもかかわらず，血中 
cortisol および 11-OHCS はほぼ正常範团にあるととが, Peterson ${ }^{36)}$ や当教室の佐藤 ${ }^{31)}$, その他によつて報 告されている，佐藤が本症に Metopirone 陚験を行なつた結果によれば，対照時の㽷中 17-OHCS はかな り増加していたのに，Metopirone に対する増加反応はほぽ正常かむしろ幾分低下していたという。さらに， Peterson $^{36)}$ および佐藤 ${ }^{31)}$ とよれば，本症では cortisol の血漿蛋白との結合率は正常であつたが，血中 cortisol 半減期は正常に比へて著明に短縮していたという。 ての様な本症における尿中および血中 cortisol 湘 定成績の解橎としては，甲状腺ホルモンの過剩か肝における活性型 cortisol の代謝を促進する可能性 ${ }^{37}$,

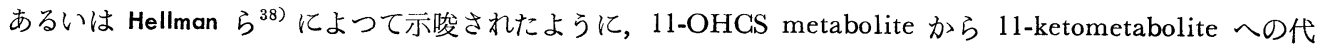
謝が特異的に促進し，後者には下垂体抑制作用がないので AGTH 分泌が促進するということが考えられ る. 何れにしても, negative feedback 機構を介して ACTH 分泌が絶えず增加し, その結果, 下垂体 AGTH 予備能はやや低下すると推定されよう。

このように，本症においては既述の HGH におけると同様に下垂体 AGTH 分泌予備能も低下傾向にあ るが，その程度は HGH にわけるよりもはるかに軽い，その差の原因は不明である．既述の如く，HGH の場合には，甲状腺ホルモンの過剩そのものが下垂体における HGH の産生を抑制する可能性が考えられ たが， thyroxine の過剩が ACTH の産生を抑制するという報告はないようである.

甲状腺機能低下症について血漿 ACTH 值を測定した報告は，まだない様である．本研究によれば治療前 の本症における血漿 ACTH 值は, 前值も insulin 低血糖に対する最高反応值も, 正常者の場合に比して 低值を示し, 下垂体 AG'TH 分泌予備能が低下している傾向が示唆された。

本症においては，尿中 17-OHCS 排泄量も cortisol 分泌量も低下しているととが報告されている ${ }^{31)}$. ま た，外因性 ACTH に対しても幾分遅延反応を示す傾向も報告されている ${ }^{31}$. 本症で，血漿 11-OHCS 值 が低值を示さず正常かやや高值に保たれていたのは，甲状腺ホルモン欠乏により steroid の代謝が遅延して いたためと考光られる。

本成績では, 甲状腺機能低下症の治療後も 3 例全例で下垂体 ACTH 分泌予備能の回復が十分でなかつた が，乙れは治療期間が短かかつたためかもしれない.

次に甲状腺機能異常症における LH の態度について考察する。

甲状腺機能立進症の女性ではしばしば月経の障害がみられる，即ち月経過少となるととが多く，月経風期

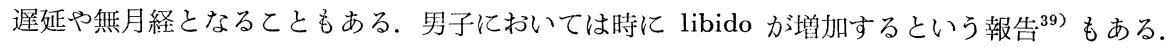

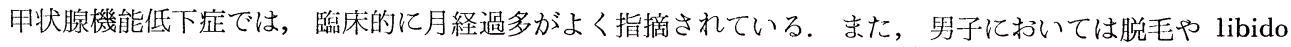
の低下等，性機能の変調を来たすてとが知られている.

甲状腺機能異常症における性ステロイドの代謝異常については詳細な研究があるが, gonadotropin の測 定をした報告は極めて少ない. Bioassay によつたものとして，Steinbeck ら ${ }^{40)}$ は無月経になつた女性の甲状 腺機能充進症では尿中 follicle stimulating hormone は增加しているてとがあると報告している.

次に radioimmunoassay により血漿 LH を測定した Schalch ら ${ }^{41)}$ の成績によると, 甲状腺機能六進症 の 5 例中 3 例で $0.5 \mathrm{~m} \mu \mathrm{g} / \mathrm{ml}$ 以下の低值を示し，また機能低下症の 5 例中，閉経後の婦人 2 例ではそれぞれ 6.2 8. $\mu \mathrm{g} / \mathrm{ml}$ と高値であつたが, 男子. 2 例と40歳の女性では $1.0 \sim 1.8 \mathrm{~m} \mu \mathrm{g} / \mathrm{ml}$ とほほ正常範囲にあつた という.

著者の研究によれば, 甲状腺機能亢進症における血漿 LH 值は, 前值は平均 $22 \mu \mathrm{g} / \mathrm{d} 1$ で正常範囲内にあ つたが, insulin 低血糖に対する最高反応值は平均 $39 \mu \mathrm{g} / \mathrm{dl}$ で正常者の平均 $61 \mu \mathrm{g} / \mathrm{d} 1$ に比してやや低值を 示した．また機能低下症でも，前值，最高值とも正常より低い值を示した。しかし治療後には，甲状腺機能 亢進症では最高值は幾分上昇し, また機能低下症でも, 前値は低值に止まつたが, 最高值はかなり正常に近 づいた. 即ち, 本研究における血漿 LH の測定成績からみて, 甲状腺機能六進症における下垂体 LH 分泌 の予備能は整度に低下しているように思われた，中村ら ${ }^{42)}$ も，甲状腺機能六進症に clomiphene を投与し て尿中 testosterone 值を測定したとてろ正常者に比して増加が少なかつたてとから, 甲状腺機能充進症に おいては hypogonadotropic hypogonadism の状態にあると推定している. 
甲状腺機能低下症に関する著者の研究によれば，下垂体 LH 分泌の予備能は低下していた. LH (HCG) と TSH の間には免疫学的に交叉反応があると報告 ${ }^{43)}$ されているので, 甲状腺機能低下症で測定される LH には，一部TSH も含まれている可能性が否定はできない.しかしそれにもかかわらず，本研究で甲状腺機 能低下症における血漿 LH 值が低下していたととは，本症における下垂体 LH 分泌予備能の低下が明らか なととを示しているといえよう.

この様に甲状腺機能異常症で下垂体 LH 分泌予備能が低下している機序については，2 通りの可能性が 考えられる. 第 1 の可能性は, 甲状腺ホルモンの過剩あるいは過少が，HGH におけると同様に，下垂体に おける gonadotropin の生成に影響をおよぼしているというととである. 第 2 の可能性は, 性腺レべルにお いて性腺ステロイドの代謝異常を介して gonadotropin の久乏を来たしているという機序である．例えば， Gallagher ら ${ }^{44)}$ は甲状腺ホルモンは androgen の代謝において $5 \alpha$-hydrogenase の活性化をもたらすとと を指摘しており, estrogen の代謝に関しては, Fishman ら ${ }^{45)}$ は 2-methoxy-estrone の増加を報告してい る. また，中村ら ${ }^{42)}$ によれば HGH を投与した際の testosterone 值は，甲状腺機能立進症では正常で， 機能低下症では減弱しているという。乙の様に考えると, 甲状腺ホルモンの過少が estrogen や testosterone の血中レベルに影響をおよぼし，乙れにより LH 分泌を間接的に左右している可能性は否定出来ないよう に思われる.

\section{V) 結 語}

甲状腺機能異常症において，血漿 HGH，AGTH および LH を radioimmunoassay によりまた血漿 11-OHCS を De Moor の方法によりそれぞれ測定し，特に insulin 負荷や arginine 負荷に対する反応の 様相から，乙れらホルモンの分泌に関する下垂体の予倩能を検索した．また，甲状腺治療後における下垂体 ホルモン分泌子備能をも併せて追求した，得られた成績は以下の通りであつた.

1 ）甲状腺機能異常症では, 機能六進症においても低下症においても, insulin 負荷に対する血漿 HGH, AGTH, LH および 11-OHCS の上昇反応ならびに arginine 負荷に対する血漿 HGH の上昇反応は, 正 常対照例の場合に比し，いずれも低下していた．低下の程度は，いずれの試験でも，機能低下症において機 能六進症におけるよりも高度であつた。

2) 下垂体ホルモンのうちでは，HGH の分泌の予備能の低下が最も著明であり，AGTH と LH そお いては軽度に止つた。

3 ）甲状腺治療後においては，血漿 HGH，ACTH，LH および 11-OHCS のすべてで反応の回復が認め られた。

4 ）甲状腺機能充進症に $\beta$-blocker を投与して insulin 負荷試験を行なつたが，負荷前に比して HGH の反応に有意の差は認められなかつた。

5 ) 甲状腺機能異常症に ${ }^{131} \mathrm{I}-\mathrm{HGH}$ を静注し，その後の血漿 ${ }^{131}$-HGH の半減期をしらべた結果では, 正常対照例に㧍ける68分に比し機能立進症の 2 例で約 10 分の短縮が，また機能低下症の 1 例で約 30 分の遅延 が認められた。

6 ）甲状腺機能異常症における下垂体前葉ホルモンの分泌の低下の原因としては, ACTH および LH に ついては体内代謝速度の変化による可能性が第 1 亿考えられた。 しかし最も低下の著明であつた HGH に ついては，甲状腺ホルモンの過剩または欠乏によつて二次的に中枢の $\mathrm{HGH}$ 分泌調節に異常を来たしてい る可能性がむしろ強いのではないかと推定された。 ただし HGH の体内代謝速度の変化による因子も否定 は出来なかつた。

本論文の要旨は, 第43回日本内分泌学会総会において発表した,

稿を終るにあたり, 御指導と御校閲をいただいた鳥飼龍生教授, 三浦清講師, 出村博, 出村黎子両博士, および御協力いただいた斎藤慎太郎博士はじめ甲状腺研究班の諸先生に感謝します. 
1) 出村 博, 出村黎子, 飯野正典, 布川 喬, 三浦 清: 日本臨林, $27: 319$, (1969).

博, 出村黎子, 三浦清, 飯野正典, 鳥飼龍生 : ホルモンと臨床, $16: 495$, (1969).

3) 出村 博 :

最新医学, $23: 945$, (1968).

Endocr. (Kobenhavn), $33: 297$, (1960).

4) De Moor, P., O. Steeno., M. Raskin and A. Hendrikx : Acta Biochem. J., 89 : 114, (1963).

5) Greenwood, F.C., W.H. Hunter and J.S. Glover :

$26: 1257,(1966)$. $16: 20$, (1968).

6) Burgess, J.A., B.R. Smith and T.J. Merimee : J. Glin. Endocr.,

7) Takeuchi, K., H. Tada and S. Suwa : Paediatria Universitatis Tokyo,

9) Katz, H.P., R. Youlton., S.L. Kaplan and M.M. Grumbach : J. Clin. Endocr., 29 : 346, (1969).

10) Rosenfeld, P.S., M.S. Wool and E. Danforth, Jr. : J. Clin. Endocr., 29 : 777, (1969).

紫芝良昌, 鎮目和夫, 清水多恵子, 久野則一, 斉藤十九子 : 日内分泌誌，44：40，(1969). Strauch, G., E. Modigliani, H. Bricaire : J. Glin. Endocr., 29 : 606, (1969).

13）井村裕夫 : 日内分泌誌，43：1260,（1968） 14) Blackard, W.G., S.A. Heidingsfelder : J. Clin. Invest., 47 : 1407, (1968). 15) Imura, H., Y. Kato., M. Ikeda., M. Morimoto., M. Yawata and M. Fukase : J. Glin. Endocr, 28 : 1079, (1968). 16) Ishida, N : Tohoku J. Exper. Med., $78: 228$, (1962). 17) Parker, M.L., R.D. Utiger and W.H. Daughaday : J. Glin. Invest., 41 : 262, (1962).

Conti, G., M. Negli, A. Isidori, O. Recchia and L. Sereno : Folia Endocr. (Roma), 15 : 721, (1962). 19) Cameron, D.P. H.G. Burger : 3rd International Cong. Endocr. 19, (1968), Excerpta Medica Foundation, Amsterdam 20) Daughaday, W.H., G.T. Peake, C.A. Birge, and I.K. Mariz : Proceedings of the first International Symposium on Growth Hormone, (1968). 238, Excerpta Medica Foundation, Amsterdam. 21) Vinik, A., B. Pimstone and B. Buchanan-lee : J. Glin. Endocr., 28 : 1534, (1968). 22) Odell, W.D., J.F. Wilber and R.D. Utiger : Recent Progr. Hormone Res., 23 : 47, (1967) 23) Demura, R., H. Demura, M. Iino, T. Nunokawa and K. Miura : Tohoku J. Exp. Med., $100: 85$, (1970). 24) Wilber, J.F and R.D. Utiger : J. Clin. Invest., $48: 2096$, (1969). 25) Fink, G.W. : Pediatrics, 40 : 881, (1967). 26) Iwatsubo, H., K. Omori, Y. Okada, M. Fukuchi, K. Miyai, H. Abe and Y. Kumahara : J. Clin. Endocr., $27: 1751$, (1967). $\quad 27)$ Brauman, H. and J. Corvilain : J. Clin. Endocr., $28: 301$, (1968).

28) Contopoulos, A.N., M.E. Simpson and A.A. Koneff : Endocrinology, $63: 642$, (1958). $\quad 29)$ Solomon, J. and R.O. Greep : Endocrinology, 65 : 158, (1959). $\quad 30)$ Ezlin, G., H.E. Swanson, J.G. Humphrey, J.W. Dawson and F.M. Hill : J. Glin. Endocr., 19 : 958, (1959).

31) 佐藤重行, 東北医学雑誌, $74: 299$, (1966). 32) Hilton, J.G., W.G. Black, W. Athos, B,Mc Hugh and G.D. Westermann : J. Glin. Endocr., 22 : 900, (1962). $\quad 33)$ Givens, J.R., R.L. Ney, W.E. Nicholson, A.L. Graber and G.W. Liddle : Glin. Res., $12: 267$ ，(1964)。 34）松倉 茂：日内分泌誌，43：505，(1967). 35) Yalow, R.S., S.M. Glick., J. Roth and S.A. Berson : J. Clin. Endocr., 24 : 1219, (1964). 36) Peterson, R.E., J. Glin. Invest., $37: 736$, (1958). $\quad 37)$ Kenny, F.M, N. Iturzaeta, C. Preeyasombat, F.H. Taylor and G.J. Migeon : J. Clin. Endocr., 27 : 1616, (1967). $\quad$ 38) Hellman, L., H.L. Bradlow., B. Zumoff and T.F. Gallagher : J. Glin. Endocr., $21: 1231$, (1961). 39) Williams, R.H. : Textbook of Endocrinology, 4th ed. (1968), 194, Saunders Co., Philadelphia. 40) Steinbeck, A.W. : Modern Trends in Human Reproduction Physiology, (1963), Butterworks, Washington 41) Schalch, D.S., A.F. Parlow, R.C. Boon and S. Reichlin : J. Clin. Invest, 47 : 665, (1968). 42) 中村真已, 井林 博, ホルモンと臨床, $13: 5$, (1965). 43) Burr, I.M., P.C. Sizonenko, S.L. Koplan and M.M. Grumbach : J. Clin. Endocr., $29: 691$, (1969). 44) Gallagher, T.F., L. Hellman, H.L. Bradlow, B. Zumoff and D.K. Fukushima : Ann. N.Y. Acad. Sci., 86 : 605, (1960). 45) Fishman, J., L. Hellman, B. Zumoff and T.F. Gallagher : J. Clin. Endocr., 25 : 365, (1965). 